\title{
TO THE PROBLEM OF THE FORMATION OF ALIEN DISCURSIVE COMPETENCE IN FUTURE DOCTORS
}

\section{G.M. Lapa, A.M. Semysiuk}

HSEE of Ukraine "Bukovynsky State Medical University", Chernivtsi

\section{Key words:}

discursive, medical tence, communicative standards, language and medicine, linguistic active profession.

Clinical and experimental pathology. Vol.16, №2 (60). P.128-130.

DOI:10.24061/17274338.XVI.2.60.2017.26

E-mail: lapagalina46 (a)gmail.com discourse, compe-

Objective - the objective of this direction in the system of teaching the students foreign languages for special goals is the development of foreign language communication, which may be proved useful to future specialists in their successful communication with foreign colleagues on such topic as analysis, examination of a patient, ability to present a patient, description of a practical case, participation in discussion, substantiation of the diagnostics choice and treatment, doctor's round of patients, use of intercultural communication in the chosen medical profession.

Material and methods. The studying of the medical discourse promotes the formation of the language image of up-to-date physician, development of his (her) communicative influence on the patient in any situation. This aspect efficacy of the medical activity depends upon speech culture of the representatives of the given linguistic communicative profession, since this principle plays not the last role for the successful diagnostics and treatment of patients, prevention of diseases.

Doctor's ability to be skillful in using words comes into the rank of his (her) professional competence; therefore, during the process of teaching foreign languages the teachers realize medical discourse for professional purposes, which verbally determines the concept "Doctor - patient - relatives".

Results. Verbal communication of doctors, medical personnel are inseparable from their professional activity, where they use different kinds of intercourse such as exchange of opinion concerning various aspects of organizing, medicinal, preventive daily work, public intercourse ( meetings, conferences), which form integral picture

of the discursive doctor's activity as curator, interlocutor, consultant, psychologist. Conclusions. In the limits of elaboration of a modern pattern of discursive competence, the representatives of medical profession must direct the whole course of training future medical men to the teaching of the medical discourse for proper use of many-sided elements of the given linguistic phenomenon.

\section{Ключевые слова: медицинский дискурс, дискурсивная компетенция, коммуникативные нормыл, язык и медиична,}

Клиническая и экспериментальная патология Т.16, №2 (60). C.128-130.

\section{К ПРОБЛЕМЕ ФОРМИРОВАНИЯ У БУДУЩИХ ВРАЧЕЙ ИНОЯЗЫЧНОЙ ДИСКУРСИВНОЙ КОМПЕТЕНТНОСТИ}

\section{Г.Н.Лапа, А.М. Семисюк}

Цель - развитие англоязычной коммуникации, которая может пригодиться будущим спещиалистам успешно общаться со своими иностранными коллегами на такие темы: анализ, обследование больного, умение представлять больного, описать случай из практики, принять участие в дискуссии, обосновать выбор диагностики и лечения, представить ход обхода больньх, принять и использовать межкультурную коммуникацию в медицине в избранной профессии.

Материал и методы. Изучение медицинского дискурса способствует формированию языкового портрета современного врача, развитию его коммуникативного влияния на паџиента, искусства общаться языком пациента в любой ситуации, эффективность этого аспекта врачебной деятельности зависит от речевой культуры данной лингвокоммуникативной профессии, поскольку этот приниип играет не последнюю роль для успешной диагностики и лечения больньх. Умение врача владеть словом входит в ранг его профессиональной компетенции, поэтому в проиессе преподавания иностранных языков преподаватель реализовывает медииинский дискурс для профессиональных ияелей, который вербально определяет концепт "врач-пациент-родственники".

Результать. Вербальная коммуникация врачей, медицинского персонала неотъемлемы от их профессиональной деятельности, в которой они используют различнье виды общения относительно разных аспектов повседневной работы: организачионной, лечебной, профилактической, публичного общения (совещания, конференции), они формируют ичелостную картину дискурсивной деятельности врача как целителя, собеседника, консультанта, психолога.

Выводы. В рамках разработки современной модели дискурсивной компетенции представителей медицинской профессии необходимо нацеливать весь курс 
подготовки будущих медиков на обучение медиџинского дискурса для корректного использования многогранных элементов данного лингвистического феномена.

\section{ДО ПРОБЛЕМИ ФОРМУВАННЯ У МАЙБУТНІХ ЛІКАРІВ ІНШОМОВНОЇ ДИСКУРСИВНОЇ КОМПЕТЕНТНОСТІ}

\section{Г.М. Лапа, А.М. Семисюк}

Мета - розвиток англомовної комунікаџії, яка може знадобитися майбутнім фахівиям успішно спілкуватися зі своїми зарубіжними колегами на такі теми: аналіз, обстеження хворого, вміння представляти хворого, описати випадок $з$ практики, взяти участь у дискусіях, обтрунтувати вибір діагностики та лікування, представити процес обходу хворих, використовувати міжкультурну комунікацію в медииині та обраній професії

Матеріал та методи. Вивчення медичного дискурсу сприяє формуванню мовного портрету сучасного лікаря, розвитку його комунікативного впливу на пацієнта, мистецтву спілкуватися мовою пацієнта, ефективність цього аспекту лікарської діяльності залежить від культури ицієї лінгвокомунікативної професії, оскільки ичей принщип відіграє не останню роль для успішної діагностики та терапії хворих. Вміння лікаря володіти словом входить до рангу його професіональної компетениії, тому в процесі викладання іноземних мов викладач реалізує медичний дискурс для досягнення професійної мети, який вербально визначає конщепт " лікар - пацієнт родичи".

Результати. Вербальна комунікація лікарів, медичного персоналу є невід'ємною частиною їхньої професійної діяльності, в якій вони використовують різні види спілкування у різноманітних аспектах повсякденної роботи: організаційної, лікувальної, профілактичної, публічних виступах (наради, конферениії), вони формують цілісну картину дискурсивної діяльності лікаря , як иілителя, співрозмовника, консультанта, психолога.

Висновки. В рамках розробки сучасної моделі дискурсивної компетенції медичних фахівців необхідно спрямовувати весь курс підготовки майбутніх лікарів на навчання медичного дискурсу для коректного використання багатогранних елементів даного лінгвістичного феномена.

\section{Introduction}

Public health service and medicine have clear interdependence with moral, ethics and obligatory mastering the art to speak patient's language. All standard documents state about the necessity of the formation of discursive culture of doctors and medical personnel, therefore, the theme and the subject of the expounded information are timely in the aspect of studying medical discourse as a social-cultural phenomenon, where the language is used as a way of intercourse, caused by the needs of practical medicine, and it should be taught as parts of doctor's ethics, where the dominant must be the motive about the curative strength of word.

The represented format of teaching medical discourse: speech situation - intercourse participants - theme - result, targeted to pragmatic aspects of teaching medical discourse must be continuous in the system of training highly qualified specialists.

The studying of the medical discourse promotes the formation of the language image of up-to-date physician, development of his (her) communicative influence on the patient in any situation. This aspect efficacy of the medical activity depends upon speech culture of the representatives of the given linguistic communicative profession, since this principle plays not the last role for the successful diagnostics and treatment of patients, prevention of diseases.

Doctor's ability to be skillful in using words comes in- to the rank of his (her) professional competence, therefore, during the process of teaching foreign languages the teachers realize medical discourse for professional purposes, which verbally determines the concept "Doctor - patient - relatives".

Linguists always paid attention to the language of medicine and its sublanguages. Medical discourse is characterized by the ramified system of terms fulfilling informative, gnosiological and reference functions, and has deep anthropological significance.

For some time past the communicative aspects of the intercourse in the sphere of medicine became the subject of study by such linguists as L.S.Beilinson [1], M.I.Barsukova, S.A.Mishlakova, I.A.Ivanchuk [2], D.B.Orobchuk [3] and others, who consider that personal contacts between a doctor and a patient are not only the exchange of information but a constituent part of the process of diagnostics, treatment and renewal of the somatic and mental health of everybody who seeks medical advice.

The main principles of medical business, based on communication, are dialogue, monologue, the elements of explanation, warning, confidential conversation and discussion, which require speech etiquette and pretence of complete refusal from excessive, tactless use of medical terminology.

The task of the linguists, studying the medical discourse, is the suggestion of the size of verbal ways and means, consisting of the usage of the generally accepted 
cliche, terminological vocabulary easily understood by the patients, discursive formulae of convictions and prejudices, calming of the patients and their relatives, clear argumentation of the decisions. Everything, listed above, must be in strict succession of speech conduct in reports, information concerning the results of treatment, prognosis for a disease, possible complications and clinical outcome.

N.Yu. Sidorova's standpoint [4], the investigator of the German medical discourse, who proposes the hypothesis according to which the basis of communication of the participants of the medical discourse is intercommunication between the main and secondary elements of speech actions, realization of which promotes the removal of asymmetrical teaching, is of great interest.

Teaching the future doctors during practical studies, we form the didactic material, based on the above stated direction in studying medical discourse, using communicative trainings "Kommunikation in Klinik und Praxis" (im beruflichen Alltagsleben in den deutschen Krankenhäusern und Praxen).

\section{Purpose}

The objective of this direction in the system of teaching the students foreign languages for special goals is the development of foreign language communication, which may be proved useful to future specialists in their successful communication with foreign colleagues on such topic as analysis, examination of a patient, ability to present a patient, description of a practical case, participation in discussion, substantiation of the diagnostics choice and treatment, doctor's round of patients, use of intercultural communication in the chosen medical profession, for example: speech situation - participants of intercourse - topic - result.

The circle of intercourse and choice of the topic must be proper, taking into account the national specific characteristics of the mentality of communicants.

Verbal communication of doctors, medical personnel are inseparable from their professional activity, where they use different kinds of intercourse such as exchange of opinion concerning various aspects of organizing, medicinal, preventive daily work, public intercourse ( meetings, conferences), which form integral picture of the discursive doctor's activity as curator, interlocutor, consultant, psychologist.

\section{Conclusions}

Proceeding from this it is possible to make a conclusion that medical discourse, as a complicated language phenomenon contains, pragmatic, social-intercultural and psychic-logical peculiarities, which may have both oral and written expression.

In the limits of elaboration of a modern pattern of discursive competence the representatives of medical profession must direct the whole course of training future medical men to the teaching of the medical discourse for proper use of many-sided elements of the given linguistic phenomenon.

\section{References:}

1.Beilinson L.S. Meditsynskii diskurs / Yazykovaya lichnost': institutsyonnyi i personalnyi diskurs [Medical Discourse / Language Person: Institutional and Personal Discourse]. Volgograd, 2000. S.105- 118. (in Russian).

2.Ivanchuk I.A. Kultura rechi $\mathrm{v}$ deiatel'nosti vracha (k probleme formirovaniia elitarnogo tipa yazykovoi lichnosti $\mathrm{v}$ professional'noi meditsyne) [Culture of speech in the activities of a doctor (to the problem of the formation of an elite type of language personality in professional medicine)] Voprosy stilistiki. Saratov. 1998. S.187-195. (in Russian).

3.Orobchuk D.B. Sotsial'no-rol'ovyi, komunikatyvnyi ta strukturno-semantychni osoblyvosti medychnogo dyskursu [Sociorole, communicative and structural-semantic peculiarities of medical institutional discourse]. Aktual'ni pytannia suspil'nykh nauk, istorii medytsyny ta movoznavstva, Chernivtsi 2014 , 3. S. 52-56. (in Ukrainian).

4.Sidorova N.Yu. Kommunikativnoe povedenie neravnostatusnykh sub'ektov meditsynskogo diskursa (na materiale nemetskogo yazyka) [Communicative Behavior of Non-Equivalent Subjects of Medical Discourse (on the Material of the German Language)] / N.Yu. Sidorova. Avtoreferat dissertatsii kandidata filologicheskikh nauk.Volgograd. 2008. - 20c. (in Russian).

5.Cicourel A.V. Language and medicine. Cambridge University. 2004. P.407-429.

6.Schrimpf V., Bahnemann M. Deutsch fur Arstinnen und Arste. Kommunikations / Training fur Klinik und Praxis. Berlin, 2009, $164 \mathrm{~S}$.

\section{Information about authors:}

Lapa Galyna Mykolaivna, senior teacher of the department of Foreign Languages of HSEE of Ukraine "Bukovinian state medical university", Chernivtsi

Semysiuk Al'bina Mykhailivna, assistant professor of the department of Foreign Languages of HSEE of Ukraine "Bukovinian state medical university", Chernivtsi

Відомості про авторів:

Лапа Галина Миколаївна, старший викладач кафедри іноземних мов ВДНЗ України "Буковинський державний медичний університет",Чернівці

Семисюк Альбіна Михайлівна, доцент кафедри іноземних мов ВДНЗ України "Буковинський державний медичний університет". Чернівці

Сведения об авторах:

Лапа Галина Николаевна, старший преподаватель кафедры иностранных языков ВГУЗ Украины "Буковинский государственный медицинский университет, Черновцы

Семисюк Альбина Михайловна, доцент кафедры иностранных языков ВГУЗ Украины "Буковинский государственный медицинский университет", Черновцы 